\title{
EFFECTS OF CHRONIC HYPERCAPNIA ON ELECTROLYTE AND ACID-BASE EQUILIBRIUM. III. CHARACTERISTICS OF THE ADAPTIVE AND RECOVERY PROCESS AS EVALUATED BY PROVISION OF ALKALI *
}

\author{
By CHARLES van YPERSELE de STRIHOU, PAUL F. GULYASSY, $\dagger$ AND \\ WILLIAM B. SCHWARTZ
}

\author{
(From the Department of Medicine, Tufts University School of Medicine, and the Renal \\ Laboratory, Pratt Clinic-New England Center Hospital, Boston, Mass.)
}

(Submitted for publication June 11, 1962; accepted September 1, 1962)

Previous studies have characterized the changes in acid-base equilibrium in dogs exposed over a prolonged period to a 12 per cent carbon dioxide atmosphere (1). Plasma bicarbonate concentration rose in a gradual curvilinear fashion over several days and became stabilized at maximal levels of 35 to $38 \mathrm{mEq}$ per $\mathrm{L}$. This adaptive response was not influenced by the level of sodium chloride intake. After the return of the dogs to room air, however, plasma bicarbonate concentration remained significantly elevated in dogs ingesting a low-salt diet. The resulting alkalosis persisted until chloride was provided, and then normal acidbase equilibrium was rapidly restored (2).

During hypercapnia, the urine remained almost free of bicarbonate and it was therefore not possible to define fully the effects of hypercapnia on the mechanism for bicarbonate reabsorption; the capacity to reabsorb completely as much as 38 $\mathrm{mEq}$ of bicarbonate per $\mathrm{L}$ of filtrate may have been rapidly engendered by hypercapnia, but not fully employed for several days because of slow renal generation of bicarbonate. In order to evaluate further the effect of a high carbon dioxide tension on the renal threshold for bicarbonate, observations have been carried out in dogs whose diets were supplemented with large quantities of sodium bicarbonate. Under these circumstances, the rise in plasma bicarbonate concentration ought not to be limited by renal ability to generate bicarbonate, but rather by renal reabsorptive capacity. Observations have also been carried out

\footnotetext{
* Supported in part by U. S. Public Health Service Grants H-759 and HTS-5309 from the National Heart Institute, and by grants from the Life Insurance Medical Research Fund and the Massachusetts Heart Association. † Medical Foundation Research Fellow, The Medical Foundation, Inc.
}

to assess the renal reabsorptive capacity after restoration of normal carbon dioxide tension in animals maintained on a high-bicarbonate, lowchloride intake.

\section{METHODS}

Balance studies were carried out on 7 female mongrel dogs weighing between 13 and $18 \mathrm{~kg}$. Observations were made during a 4- to 7-day control period, a 6- to 13-day period in a high $\mathrm{CO}_{2}$ atmosphere, and a 9- to 23-day period of recovery.

Each day the animals were fed $30 \mathrm{~g}$ per $\mathrm{kg}$ of body weight of a synthetic diet of previously described composition (1). The intrinsic electrolyte content of the diet was $1 \mathrm{mEq}$ sodium, less than $1 \mathrm{mEq}$ chloride, and less than $0.1 \mathrm{mEq}$ potassium per $100 \mathrm{~g}$. The daily intake was supplemented with 5.5 to 6.5 mmoles per $\mathrm{kg}$ of body weight of sodium bicarbonate and with 2.5 to 3.0 $\mathrm{mEq}$ per $\mathrm{kg}$ of potassium as phosphate, $4 \mathrm{HPO}_{4}^{--/ 1}$ $\mathrm{H}_{2} \mathrm{PO}_{4}^{-}$. The daily intake was fed in two parts throughout the study. Additional electrolytes were provided as described below. The study was divided into the following three periods.

Period I. Adaptation to high $\mathrm{CO}_{2}$ atmosphere. The animals were maintained in a $12 \pm 1$ per cent $\mathrm{CO}_{2}$ atmosphere according to a technique previously described (1). On day 1,1 or 2 hours after the morning feeding, the $\mathrm{CO}_{2}$ concentration in the cage was increased to approximately 12 per cent over a period of 2 to 3 hours. Each morning and evening, the animals were removed briefly from the cage for feeding and other routine procedures; the total time out of the high $\mathrm{CO}_{2}$ atmosphere was about 30 to 40 minutes daily. All blood samples were taken while the dogs breathed a mixture of 12 per cent $\mathrm{CO}_{2}, 20$ per cent oxygen, and 68 per cent nitrogen through a mask.

Period II. Recovery-return to room air. The atmosphere in the cage was abruptly restored to normal, and metabolic observations were continued until plasma bicarbonate was stabilized for at least 2 days. Then, 4 dogs were provided for a period of 4 to 5 days with an additional daily intake of electrolytes -2 to 3 mmoles per $\mathrm{kg}$ of $\mathrm{KHCO}_{3}$ for dogs $\mathrm{C}, \mathrm{E}$, and $\mathrm{Z}$, and 3 mmoles per $\mathrm{kg}$ of sodium bicarbonate for $\operatorname{dog} \mathrm{D}$-and were then returned to their basal intake for 2 to 4 days. 
Period III. Recovery-administration of chloride supplement. Dogs L, S, B, and D were provided with 3 to 6 mmoles per kg per day $\mathrm{NaCl}$ and dogs $\mathrm{Z}, \mathrm{C}$, and $\mathrm{E}$, with 2 to 3 mmoles per $\mathrm{kg}$ per day $\mathrm{KCl}$ for 1 to 5 days. Observations were continued in five dogs for 3 to 5 days after withdrawal of the chloride load, but since no significant change occurred over this interval, detailed data are not presented.

The analytic methods have been described previously (3). Net alkali excretion has been calculated as $\left[\mathrm{HCO}_{3}^{-}\right.$ $-\left(\mathrm{NH}_{4}+\right.$ titratable acid $\left.)\right]$. Delta net alkali is expressed as the change from the average output during the last 3 to 7 days of the preceding period. The daily balance was calculated as the net intake minus the combined output in urine, stool, and blood sample. Each $20 \mathrm{ml}$ of blood withdrawn was considered to contain $2 \mathrm{mEq}$ of chloride and $3 \mathrm{mEq}$ of sodium. In $\operatorname{dog} \mathrm{D}$, the urine was contaminated on Day 7 of hypercapnia by vomitus; analysis for electrolytes was performed on a nitric acid digest of the mixture.
Supplementary studies on acute changes in plasma bicarbonate concentration and bicarbonate excretion after bicarbonate feeding. Three additional dogs were placed in 12 per cent $\mathrm{CO}_{2}$ for 2 hours and then force-fed with half their daily diet and half their supplementary $\mathrm{NaHCO}_{3}$. Over the next 5 to 6 hours, multiple blood samples were drawn for determination of $\mathrm{CO}_{2}, \mathrm{pH}$, and other electrolytes. In two animals, voided or catheterized urine specimens were obtained for measurement of $\mathrm{pH}$ and $\mathrm{CO}_{\text {, }}$ content at intervals throughout this period. These studies were conducted in unanesthetized animals, without interruption of hypercapnia, by use of an environmental chamber.

\section{RESULTS}

At the end of the control period, average plasma concentrations were: $147 \mathrm{mEq}$ per $\mathrm{L}$ sodium, 23 $\mathrm{mEq}$ per $\mathrm{L}$ bicarbonate, $109 \mathrm{mEq}$ per $\mathrm{L}$ chloride, and $3.9 \mathrm{mEq}$ per $\mathrm{L}$ potassium. Urine bicarbonate

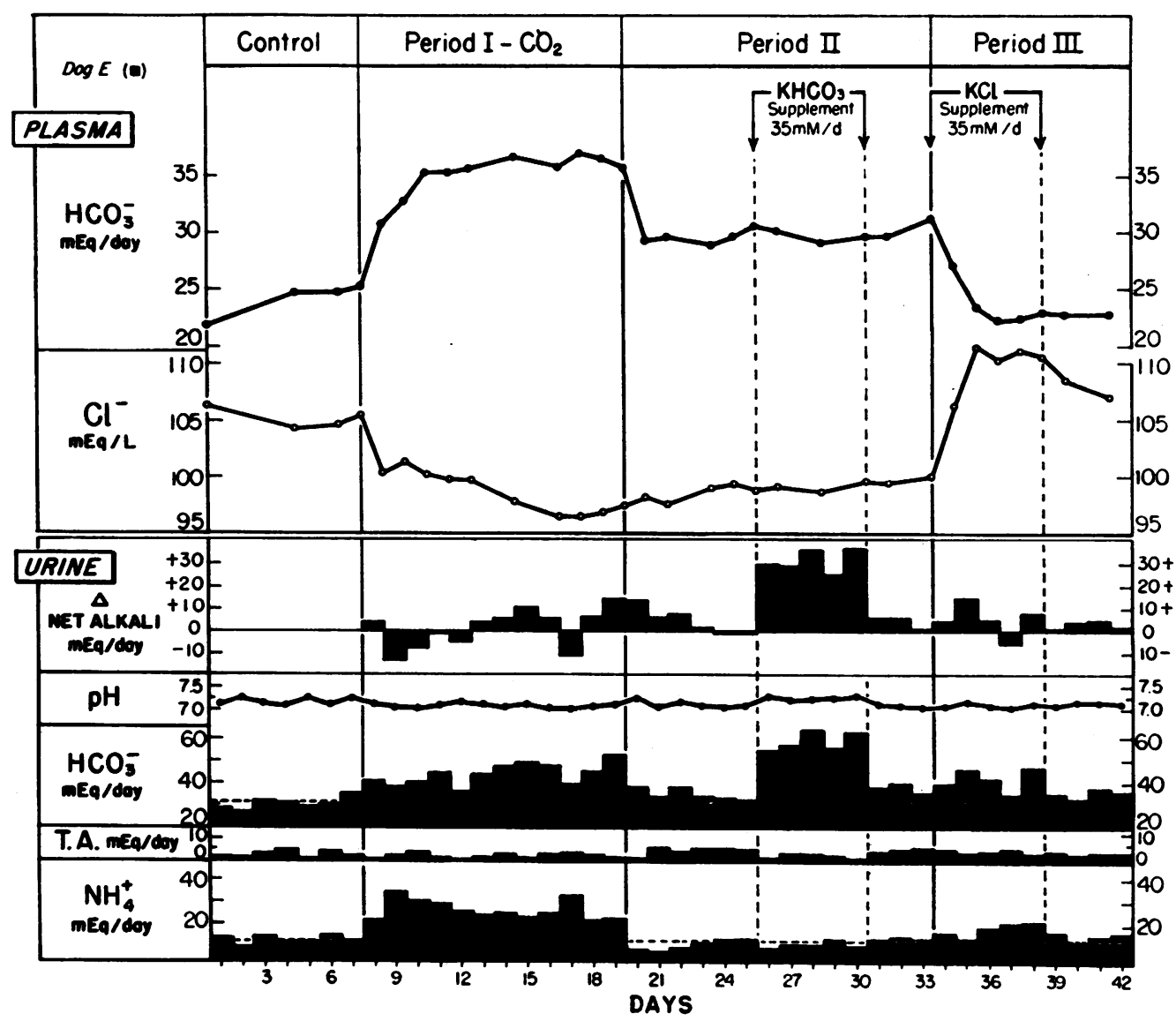

Fig. 1. Changes in acid-base equilibrium and plasma chloride concentration during adapTATION TO AND RECOVERY FROM CHRONIC HYPERCAPNIA IN A DOG INGESTING SODIUM BICARBONATE (6.5 MMOLES PER KG PER DAY). Dashed horizontal lines represent mean daily excretion during the control period. Values for net alkali excretion [bicarbonate-(ammonium + titratable acid)] represent changes from mean daily excretion during the control period. 


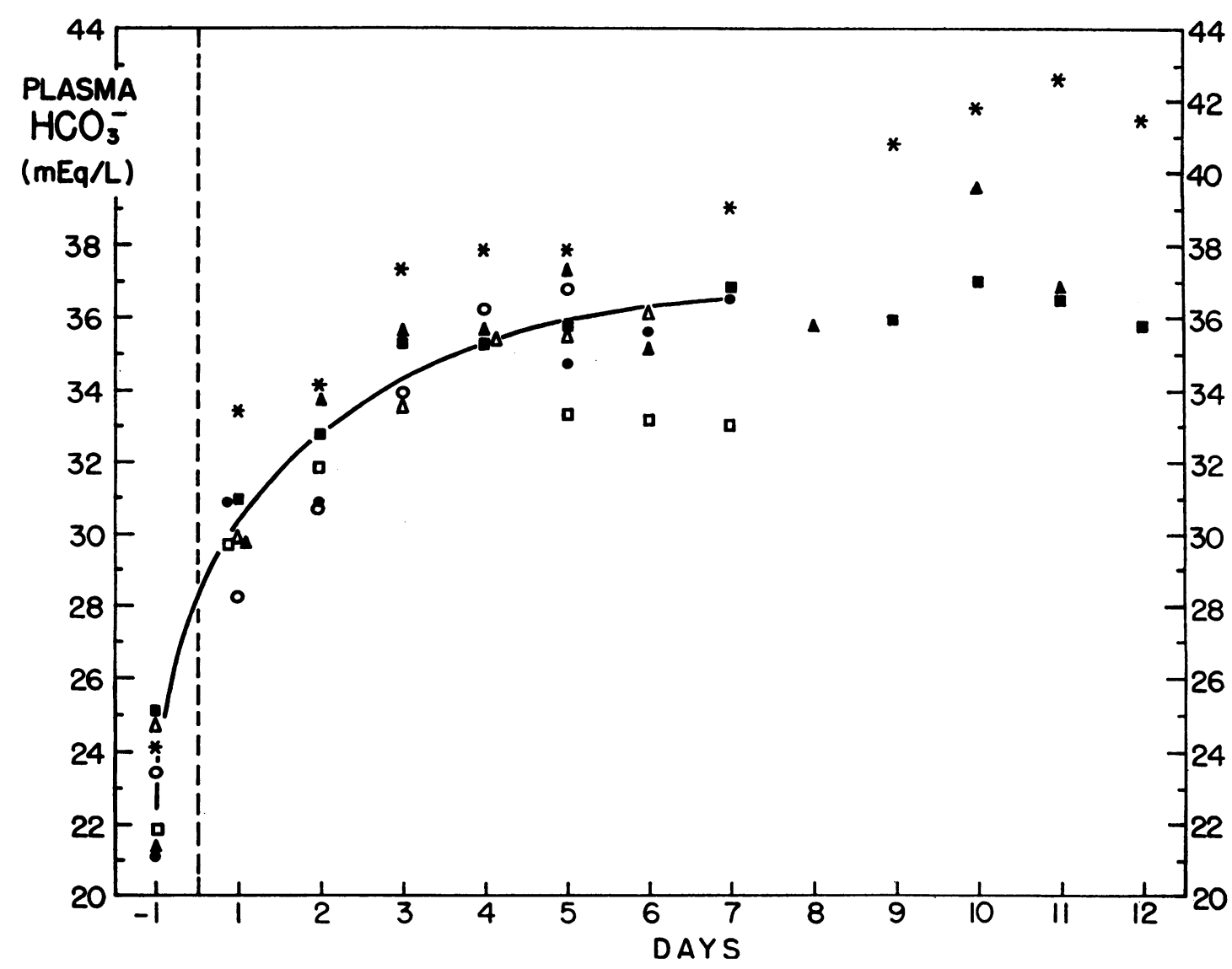

Fig. 2. Plasma bicarbonate concentration during exposure to a high $\mathrm{CO}_{2}$ atmosphere in dogs ingestING SOdiUm BICARbonate (5.5 to 6.5 MMOLES PER KG PER DAY). Day -1 refers to the last day of the control period. Dog D (*) vomited on Day 7. The solid curved line has been taken from a previous paper (1) describing changes in plasma bicarbonate in dogs exposed to a 12 per cent $\mathrm{CO}_{2}$ atmosphere while ingesting an alkali-free intake.

excretion averaged $35 \mathrm{mEq}$ per day, with a range from 26 to $54 \mathrm{mEq}$. Figure 1 presents in detail the results of a typical study. The remaining figures and Table I show collective data.

\section{Period I. High $\mathrm{CO}_{2}$ atmosphere}

Acid-base balance. As seen in Figure 2, plasma bicarbonate concentration rose after one day in the high $\mathrm{CO}_{2}$ atmosphere to a mean value of 30 $\mathrm{mEq}$ per L. On subsequent days, plasma bicarbonate continued to rise slowly, reaching a plateau of approximately $36 \mathrm{mEq}$ per L 3 to 4 days after induction of hypercapnia. At the end of the period, plasma $\mathrm{pH}$ was in the range of 7.20 to 7.25 . On day 1, alkali excretion rose above control levels in six of seven animals, with an average delta net alkali of $+10 \mathrm{mEq}$, owing entirely to an in- crease in $\mathrm{HCO}_{3}$ excretion (Figure 1). Over the next 2 to 3 days, as plasma bicarbonate rose to its maximal level, net alkali excretion fell. Cumulative delta net alkali excretion over days 2 to 4 averaged $-41 \mathrm{mEq}$, with a range from -20 to $-112 \mathrm{mEq}$. This fall was due entirely to an increase in ammonia excretion; bicarbonate excretion remained at or above control levels throughout the period.

Chloride, sodium, and potassium. On the first day, plasma chloride concentration fell to an average of $105 \mathrm{mEq}$ per L. Over the next 5 to 6 days there was a further drop to a level of approximately $98 \mathrm{mEq}$ per L (Figure 1). Moderate chloruresis occurred during the first 3 to 6 days, and then chloride excretion fell to control levels. The cumulative chloride losses for the period ranged from 39 to $83 \mathrm{mEq}$ (Table I). There 
were no significant changes in plasma sodium concentration or in sodium balance. By the end of the period, plasma potassium concentration had fallen to an average of $3.4 \mathrm{mEq}$ per $\mathrm{L}$. Potassium excretion increased on the first day in $\mathrm{CO}_{2}$ by an average of $26 \mathrm{mEq}$, but subsequently returned to approximately control levels. Balance data are shown in Table I.

\section{Period II. Recovery-return to room air}

Acid-base balance. By the end of 1 day in room air, plasma bicarbonate had dropped by an average of $6 \mathrm{mEq}$ to a mean level of $30 \mathrm{mEq}$ per $\mathrm{L}$ (Figure 3). $\mathrm{pH}$ rose from its previously acidotic levels to an average of 7.48. The fall in plasma bicarbonate concentration was accompanied by a rise in the unmeasured anion level, averaging $+3 \mathrm{mEq}$ per $\mathrm{L}$, and a decrease in sodium concentration, averaging $-3 \mathrm{mEq}$ per $\mathrm{L}$. During the subsequent 5 to 6 days, there were no further significant changes. There was no significant difference in the daily net alkali excretion rate as compared with either the end of the $\mathrm{CO}_{2}$ period or the control period. In the four animals given

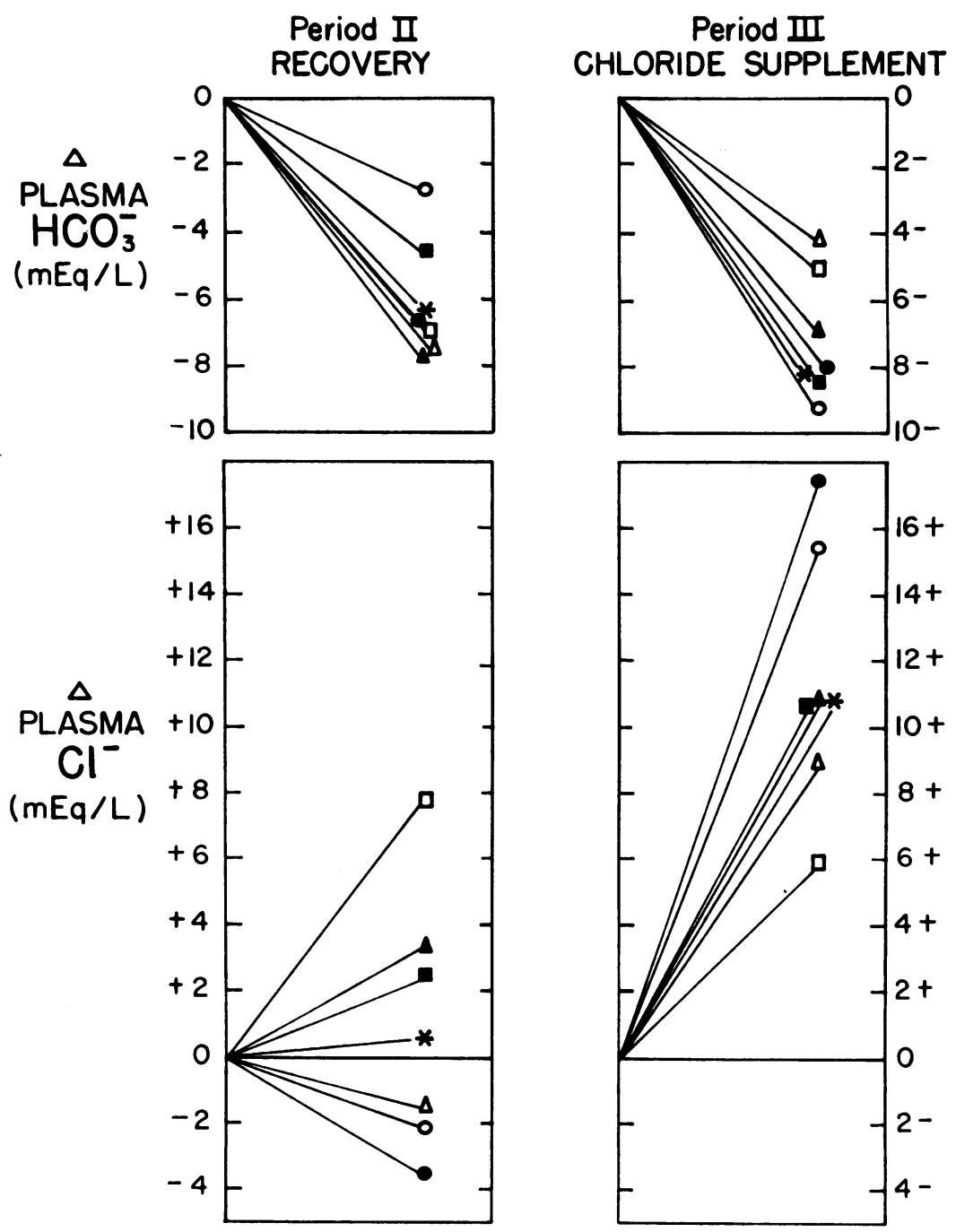

Fig. 3. Changes in plasma bicarbonate and Chloride concentrations DURING RECOVERY FROM CHRONIC HYPERCAPNIA. For Period II, changes have been calculated as the difference between plasma concentration on the last day in $\mathrm{CO}_{2}$ and the last day before chloride administration; for Period III, as the difference between the last day before chloride administration and the last day of chloride repletion. 
TABIE I

Changes in electrolyte balance*

\begin{tabular}{|c|c|c|c|c|c|c|c|c|c|c|}
\hline \multirow[b]{2}{*}{$\begin{array}{c}\text { Experimental } \\
\text { period }\end{array}$} & \multirow[b]{2}{*}{ Dog } & \multirow[b]{2}{*}{ Time } & \multicolumn{2}{|c|}{ Weight } & \multicolumn{6}{|c|}{ External balance } \\
\hline & & & $\frac{\text { We }}{\text { Initial }}$ & $\frac{\text { Final }}{\text { Final }}$ & $\mathrm{Cl}$ & $\mathrm{Na}$ & $\mathrm{Cl}-\frac{\mathrm{Na}}{1.3}$ & $\mathrm{~K}$ & $\begin{array}{l}\text { K corrected } \\
\text { for } \mathrm{N}+\end{array}$ & $N$ \\
\hline \multirow{8}{*}{$\begin{array}{l}\text { I. High } \mathrm{CO}_{2} \\
\text { atmosphere }\end{array}$} & & days & $\mathrm{kg}$ & $\mathrm{kg}$ & $m E q$ & $m E q$ & $m E q$ & $m E q$ & $m E \boldsymbol{q}$ & $g$ \\
\hline & $\mathrm{L}$ & 6 & 13.0 & 11.8 & -39 & -28 & -17 & -24 & -20 & -1.7 \\
\hline & $\mathrm{S}$ & 13 & 18.4 & 17.3 & -66 & +54 & -107 & -8 & -5 & -1.0 \\
\hline & B & 7 & 16.1 & 16.3 & -51 & -13 & -41 & -78 & -61 & -6.1 \\
\hline & D & 12 & 13.2 & 12.9 & $-82 \ddagger$ & +65 & -132 & +7 & -18 & +9.1 \\
\hline & $Z$ & 7 & 16.1 & 14.8 & -83 & -34 & -57 & -49 & -7 & -15.4 \\
\hline & $\mathrm{C}$ & 7 & 14.8 & 14.0 & -47 & +18 & -61 & -3 & -18 & +5.2 \\
\hline & $\mathrm{E}$ & 12 & 13.0 & 12.5 & -50 & +15 & -62 & -31 & -33 & +0.3 \\
\hline \multirow{7}{*}{ II. } & L & 6 & 11.8 & 11.6 & -10 & -3 & -8 & -13 & -9 & -1.5 \\
\hline & $\mathrm{S}$ & 5 & 17.3 & 17.1 & 0 & +9 & -7 & -23 & -40 & +6.4 \\
\hline & B & 7 & 16.3 & 15.2 & -3 & +56 & -46 & +14 & +1 & +5.1 \\
\hline & D & 14 & 12.9 & 12.9 & +4 & +87 & -63 & +6 & -47 & +19.6 \\
\hline & $Z$ & 14 & 14.8 & 14.8 & -2 & +129 & -101 & +22 & -26 & +17.5 \\
\hline & $\mathrm{C}$ & 11 & 14.0 & 13.8 & -6 & -6 & -1 & -63 & -113 & +18.6 \\
\hline & $\mathrm{E}$ & 14 & 12.7 & 12.5 & -5 & +31 & -29 & +14 & -20 & +12.7 \\
\hline \multirow{7}{*}{$\begin{array}{l}\text { III. Chloride } \\
\text { supplement } \S\end{array}$} & L & 1 & 11.6 & 11.8 & +68 & +66 & +17 & +17 & +7 & +3.5 \\
\hline & $\mathrm{S}$ & 3 & 17.1 & 17.4 & +97 & +95 & +24 & +44 & +24 & +7.1 \\
\hline & B & 4 & 15.2 & 15.7 & +66 & -10 & +74 & +14 & +4 & +3.8 \\
\hline & $\mathrm{D}$ & 2 & 12.9 & 13.2 & +63 & +26 & +43 & +19 & +15 & +1.5 \\
\hline & $Z$ & 4 & 14.8 & 15.0 & +93 & +24 & +75 & +54 & +49 & +1.6 \\
\hline & C & 5 & 13.8 & 14.3 & +120 & +66 & +69 & +65 & +32 & +12.2 \\
\hline & $\mathrm{E}$ & 5 & 12.5 & 13.0 & +63 & +18 & +49 & +33 & +18 & +5.6 \\
\hline
\end{tabular}

* The cumulative balances refer only to the changes that occurred during the individual period.

* The cumulative balances refer only to

Value includes approximately $30 \mathrm{mEq}$ lost in vomitus on day 7.

$\$$ Chloride provided as $\mathrm{NaCl}$ to Dogs $\mathrm{L}, \mathrm{S}$. B, and $\mathrm{D}$ and as $\mathrm{KCl}$ to Dogs $\mathrm{Z}, \mathrm{C}$, and $\mathrm{E}$.

supplements of sodium or potassium bicarbonate, the increment in alkali load was recovered in the urine; plasma bicarbonate concentration was unaffected.

Chloride, sodium, and potassium. Plasma chloride concentration showed no consistent or significant trend during the recovery period (Figures 1 and 3 ) and averaged $99 \mathrm{mEq}$ per $\mathrm{L}$. Cumulative balances are shown in Table I. Plasma potassium fell to a mean level of $2.9 \mathrm{mEq}$ per $\mathrm{L}$. The sodium and potassium bicarbonate supplements produced no significant change either in plasma composition or in electrolyte balance.

\section{Period III. Recovery-administration of chloride}

Acid-base balance. During the administration of chloride, as either $\mathrm{NaCl}$ or $\mathrm{KCl}$, plasma bicarbonate concentration fell to an average of $23 \mathrm{mEq}$ per $\mathrm{L}$, and $\mathrm{pH}$ returned to the normal range. The total fall in bicarbonate concentration averaged 7 $\mathrm{mEq}$ per L (Figure 3 ). There was a cumulative increase in net alkali excretion averaging $13 \mathrm{mEq}$.

Chloride, sodium, and potassium. Plasma chloride concentration rose by an average of $14 \mathrm{mEq}$ per $\mathrm{L}$ to a mean level of $113 \mathrm{mEq}$ per $\mathrm{L}$ (Figures 1 and 3 ). Cumulative chloride retention ranged from 63 to $120 \mathrm{mEq}$ (Table I). Plasma potassium rose to an average level of $3.9 \mathrm{mEq}$ per $\mathrm{L}$. Cumulative retention of electrolytes is shown in Table I.

Miscellaneous. Calculated extracellular fluid volume decreased by an average of $0.3 \mathrm{~L}$ during hypercapnia, remained stable over Period II, and rose by an average of $0.4 \mathrm{~L}$ after chloride administration. Phosphate excretion remained at control levels throughout the study except for a slight increase, averaging 6 mmoles, during the first day of hypercapnia and a moderate decrease, average 14 mmoles, during the first day in room air. There was significant retention of nitrogen during Periods II and III (Table I).

Throughout the study, from Periods I through III, plasma creatinine, organic acid excretion, and sulfate excretion (measured in $\operatorname{dog} \mathrm{E}$ only) showed no significant change. The electrolyte losses in the stool remained essentially in the control range throughout, and averaged $4 \mathrm{mEq}$ sodium, $1 \mathrm{mEq}$ potassium, and less than $1 \mathrm{mEq}$ chloride daily. 
Supplementary studies on acute changes in plasma bicarbonate concentration after bicarbonate feeding. Studies were carried out in three animals after a feeding of half the daily sodium bicarbonate supplement. Plasma bicarbonate concentration rose over a period of 1 to 3 hours to peak levels of $36.0,34.5$, and $33.5 \mathrm{mEq}$ per $\mathrm{L}$, and fell slowly thereafter. The following morning the mean plasma bicarbonate concentration was $30.0 \mathrm{mEq}$ per L. Peak values observed after feeding fell short by $3.0,4.0$, and $2.5 \mathrm{mEq}$ per L, respectively, of the final levels achieved after 4 to 6 days of exposure to $\mathrm{CO}_{2}$. As the plasma bicarbonate concentration rose after feeding, 16 and 17 $\mathrm{mEq}$ bicarbonate were excreted by the two animals from which urine was collected. Significant alkali excretion-24 and $25 \mathrm{mEq}$ - continued as plasma bicarbonate subsequently fell from the peak level toward preabsorptive concentrations.

These studies exclude the theoretical possibility that an elevation in renal bicarbonate threshold to 36 to $38 \mathrm{mEq}$ per $\mathrm{L}$ was masked by rapid absorption and excretion of bicarbonate; if rapid intestinal absorption had led to an abrupt rise of plasma bicarbonate concentration far alove 36 to $38 \mathrm{mEq}$ per L, a large fraction of the administered bicarbonate might have been spilled by the kidney before significant equilibration with extravascular fluids had occurred.

\section{DISCUSSION}

The present study demonstrates that despite provision of liberal quantities of alkali, plasma bicarbonate concentration did not reach maximal levels until 3 to 4 days after induction of hypercapnia. Over this interval, bicarbonate excretion continued at a high level, indicating that a gradual rise in bicarbonate reabsorptive capacity limited the rate at which the plasma bicarbonate concentration increased. It is of interest to note, as shown in Figure 2, that the pattern of rise in plasma bicarbonate was similar to that shown previously in animals ingesting an alkali-free intake (1). ${ }^{1}$ It thus appears that the rise in plasma

\footnotetext{
${ }^{1}$ In the previous study on an alkali-free intake (1), the data were interpreted as indicating a slight rise in plasma concentration between days 4 and 7 . Exact definition, however, of the slope between these latter points is difficult in view of the wide scatter of the data. Whether or not there is a significant difference between the two studies over this interval cannot be decided.
}

concentration in these previous studies closely reflected the gradual rise in the threshold for bicarbonate; since these animals excreted urine almost free of bicarbonate, it would seem that the rate of bicarbonate generation and the rise in threshold were closely linked.

The highest spontaneous reabsorptive capacity ${ }^{2}$ seen in the present chronic studies corresponds closely to the forced reabsorptive capacity ${ }^{3}$ observed during acute hypercapnia $(4,5)$. Despite this superficial resemblance, closer examination reveals striking differences in the characteristics of the reabsorptive mechanisms under these two circumstances. In acute respiratory acidosis, during intravenous administration of sodium bicarbonate, there was a continuous and increasing excretion of bicarbonate as plasma level was elevated above $30 \mathrm{mEq}$ per $\mathrm{L}$. The maximal bicarbonate reabsorption of $38 \mathrm{mEq}$ per $\mathrm{L}$ was achieved only at plasma concentrations significantly higher than $38 \mathrm{mEq}$ per L. If this degree of incomplete reabsorption persisted during prolonged hypercapnia, plasma bicarbonate concentration could not be spontaneously sustained above $30 \mathrm{mEq}$ per $\mathrm{L}$. The present data demonstrate that only after 3 to 4 days of hypercapnia is the bicarbonate reabsorptive capacity sufficiently enhanced so that no bicarbonate is excreted at plasma levels below 36 to $38 \mathrm{mEq}$. Only at that time can plasma bicarbonate concentration rise to approximately $36 \mathrm{mEq}$ per L.

Just as the spontaneous reabsorptive capacity increases during adaptation, so the forced reabsorptive capacity rises, reaching a final level as high as 50 to $55 \mathrm{mEq}$ per $\mathrm{L}$, at plasma bicarbonate concentrations of 70 to $80 \mathrm{mEq}$ per L (6). Bicarbonate excretion, however, begins at plasma levels well below those necessary to saturate reabsorptive capacity (6) and, as demonstrated in the present study, is so great that even a large oral intake of bicarbonate fails to raise the plateau

\footnotetext{
2 The term spontaneous reabsorptive capacity is used to designate the amount of bicarbonate reabsorbed per unit of glomerular filtrate in the fasting animal. For all practical purposes this value can be assumed to equal the plasma bicarbonate concentration in the fasting animal.

$:$ The term forced reabsorptize capacity will be used to designate the maximum amount of bicarbonate reabsorbed per unit of glomerular filtrate when plasma bicarbonate is markedly elevated by intravenous loading.
} 
level in the plasma above that observed on an alkali-free intake (1).

It is apparent that a direct augmentation of hydrogen transfer by way of a mass action effect of $\mathrm{CO}_{2}$ cannot account for the progressive rise in spontaneous reabsorptive capacity that occurs in the presence of a constant elevation of $\mathrm{pCO}_{2}$. The mechanism responsible for this adaptation remains obscure, although it is clear that some rate limit present in acute respiratory acidosis is modified by long-sustained hypercapnia. It has previously been demonstrated that in acute respiratory acidosis the relationship between plasma bicarbonate concentration and rate of bicarbonate reabsorption exhibited the characteristics of MichaelisMenten kinetics (4). ${ }^{4}$ It was proposed that an enzymatic reaction was rate-limiting in the reabsorptive process, and it was further suggested that the rate limit may be determined by the activity of carbonic anhydrase. If such were the case, it might be postulated that chronic exposure to hypercapnia leads to an increased carbonic anhydrase activity that is responsible for the adaptive process. Although in vitro studies in rats exposed chronically to $\mathrm{CO}_{2}$ do not show an increase in renal carbonic anhydrase activity (8), this type of observation in no way excludes the possibility that there is an in vivo increase in activity. On the other hand, it is possible that either some other enzyme or that some factor of a nonenyzmatic nature is responsible for both the original rate limit and its removal. If, for example, chronic hypercapnia were directly responsible for inhibiting chloride reabsorption, this change itself could conceivably account for the rise in bicarbonate threshold (9).

The data suggest that the abrupt rise in plasma bicarbonate concentration observed on the first day of exposure to carbon dioxide was the result of tissue buffering, since on this day alkali excre-

4 Over plasma bicarbonate concentrations of 25 to 55 $\mathrm{mEq}$ per $\mathrm{L}$, the data were found to fit a rectangular hyperbola. It has subsequently been reported that at higher plasma concentrations the reabsorptive rate deviates from this pattern (5). Such findings in no way argue against the possibility that at lower and more physiological substrate concentrations a step characterized by MichaelisMenten kinetics may be rate-limiting; it is well known that deviations from ideal Michaelis-Menten kinetics occur commonly in vitro at high substrate concentrations (7). tion actually rose above control levels. Over the subsequent 2 to 3 days, net alkali excretion fell sufficiently to account fully for the further rise in extracellular bicarbonate concentration and, in most animals, to account for a comparable degree of alkalinization throughout body water. It is of interest that the fall in net alkali excretion was less than half as large as the increase in net acid excretion previously reported in hypercapneic dogs ingesting a bicarbonate-free intake (1). Since the increment in plasma bicarbonate concentration was virtually identical in both studies, it seems possible that this discrepancy could be the result of differences in endogenous acil load during the period of hypercapnia. This view is suggested by the observation that, in the present study, there were no significant changes in nitrogen balance, whereas in previous studies nitrogen balance was strongly negative (1).

During the first 24 hours after the animals' removal from the $\mathrm{CO}_{2}$ atmosphere, plasma bicarbonate concentration fell by an average of $6 \mathrm{mEq}$ per $\mathrm{L}$ to a mean of $30 \mathrm{mEq}$ per $\mathrm{L}$, where it remained despite a continued high bicarbonate intake. These data demonstrate a reduction in bicarbonate threshold in the face of persistent chloride deficiency. They further suggest that the posthypercapneic fall in plasma bicarbonate concentration observed previously on a low-chloride, bicarbonate-free diet was due to a reduction in threshold rather than to failure of the kidney to regenerate bicarbonate lost as the result of tissue buffering (2).

\section{SUM MARY}

Large quantities of alkali have been administered to seven dogs during and after chronic exposure to a 12 per cent carbon dioxide atmosphere in order to evaluate the characteristics of the adaptive and recovery process. It has been demonstrated that despite provision of 5.5 to 6.5 mmoles of sodium bicarbonate per $\mathrm{kg}$ of body weight, plasma bicarbonate concentration did not reach its maximal level of approximately $36 \mathrm{mEq}$ per $L$ until 3 to 4 days after induction of hypercapnia. These data suggest that a constant elevation of $\mathrm{pCO}_{2}$ induces a slow adaptive process that is responsible for the progressive increase in the capacity of the kidney to completely reabsorb bi- 
carbonate. This pattern of rise in plasma bicarbonate concentration is similar to that previously observed in animals on an alkali-free intake; since the animals in these earlier studies excreted an almost bicarbonate-free urine, it appears that in chronic hypercapnia the rate of bicarbonate generation by the kidney and the rise in bicarbonate threshold are closely linked.

After the animals' return to room air, plasma bicarbonate level fell to approximately $30 \mathrm{mEq}$ per $\mathrm{L}$, a response identical to that previously noted in animals on a low-chloride, alkali-free diet. Acid-base equilibrium was subsequently restored to normal, with plasma bicarbonate $23 \mathrm{mEq}$ per $\mathrm{L}$, when chloride was administered as either the sodium or potassium salt. These findings indicate that the increase in renal reabsorptive capacity induced by chronic hypercapnia can be partly eliminated by restoration of a normal plasma carbon dioxide tension without change in the degree of chloride deficiency or hypochloremia.

\section{REFERENCES}

1. Polak, A., Haynie, G. D., Hays, R. M., and Schwartz, W. B. Effects of chronic hypercapnia on electrolyte and acid-base equilibrium. I. Adaptation. J. clin. Invest. 1961, 40, 1223.
2. Schwartz, W. B., Hays, R. M., Polak, A., and Haynie, G. D. Effects of chronic hypercapnia on electrolyte and acid-base equilibrium. II. Recovery, with special reference to the influence of chloride intake. J. clin. Invest. 1961, 40, 1238.

3. Atkins, E. L., and Schwartz, W. B. Factors governing correction of the alkalosis associated with potassium deficiency; the critical role of chloride in the recovery process. J. clin. Invest. 1962, 41, 218

4. Schwartz, W. B., Falbriard, A., and Lemieux, G. The kinetics of bicarbonate reabsorption during acute respiratory acidosis. J. clin. Invest. 1959, 38, 939.

5. Rector, F. C., Jr., Seldin, D. W., Roberts, A. D., Jr., and Smith, J. S. The role of plasma $\mathrm{CO}_{2}$ tension and carbonic anhydrase activity in the renal reabsorption of bicarbonate. J. clin. Invest. 1960, 39, 1706

6. Sullivan, W. J., and Dorman, P. J. The renal response to chronic respiratory acidosis. J. clin. Invest. 1955, 34, 268.

7. Dixon, M., and Webb, E. C. Enzymes. New York, Academic Press, 1958, pp. 81-89.

8. Carter, N. W., Seldin, D. W., and Teng, H. C. Tissue and renal response to chronic respiratory acidosis. J. clin. Invest. 1959, 38, 949.

9. Gulyassy, P. F., van Ypersele de Strihou, C., and Schwartz, W. B. On the mechanism of nitrateinduced alkalosis. The possible role of selective chloride depletion in acid-base regulation. J. clin. Invest. 1962, 41, 1850 . 